\title{
Investigations of the performance of facades made of ETICS with polystyrene under external fire exposure and fire safety measures for their improvement
}

\author{
Ingolf Kotthoff ${ }^{1}$, Sebastian Hauswaldt ${ }^{2}$, Olaf Riese ${ }^{3}$ and Jan Riemesch-Speer ${ }^{4}$ \\ ${ }^{1}$ Ingenieurbüro für Brandschutz bei Fassaden (IBF), Stadtlengsfeld, Germany \\ ${ }^{2}$ MFPA Leipzig GmbH, Leipzig, Germany \\ ${ }^{3}$ Technische Universität Braunschweig, Braunschweig, Germany \\ ${ }^{4}$ Deutsches Institut für Bautechnik (DIBt), Berlin, Germany
}

\section{INTRODUCTION}

Exposure to flames of a fully developed room fire venting out of an external wall opening after flashover is most commonly used as the reference fire scenario for assessing the fire performance of external wall cladding systems. This is reflected by various testing standards (e.g. ISO 13785-2 [1], E DIN 410220 [2]). The impact of other fire scenarios had been judged as less critical or most similar in the past. Hence, there was a widespread opinion that other scenarios were covered by these fire tests (cf. [3]). This assumption has also underlain assessment of ETICS fire performance.

Only in spring 2013 was there an fire scenario had been introduced in the discussion on fire performance assessment of external wall cladding systems in Germany - the exposure to fires outside near the base of the building (e.g. waste containers, small cars etc.), and this just for ETICS based on polystyrene insulation material.

\section{DISCUSSONS IN GERMAN BUILDING REGULATORY BOARDS}

After some particularly serious fires and extensive media coverage of these events, the Conference of the Länder ministers responsible for building (Bauministerkonferenz, abbreviated as BMK) decided in autumn 2012 to set up a project group to evaluate a list of fire incidents involving external thermal insulation composite systems (ETICS) based on polystyrene. This list had been provided by the fire brigades. After evaluation of the list, the group should recommend appropriate measures (if necessary) to improve the fire performance of polystyrene-based ETICS. In several meetings, the project group analysed 25 fire incidents in total. Approved ETICS based on polystyrene were involved in 18 out of 25 cases. In a report to the $B M K$ in March 2013 [4], the project group characterised the fire incidents as follows:

- In most cases, the ETICS were exposed to fires from outside the building - e.g. burning waste containers or smaller bulky waste piles.

This is an Open Access article distributed under the terms of the Creative Commons Attribution License 2.0, which permits unrestricted use, distribution, and reproduction in any medium, provided the original work is properly cited. 


\section{MATEC Web of Conferences}

- In some cases, the fire spread from an annex to the facade - sometimes facilitated by damages of the facade or poor workmanship of the connections between the annex and the main building.

- In one case, the fire occurred during the construction phase. The ETICS was not yet completed, and the fire was caused by a large quantity of polystyrene insulation material stored near the building.

- Only in one case, the ETICS had been exposed to flames of a fully developed room fire.

- In one case with unacceptable fire development, the design of the ETICS and the building itself strongly deviated from standard practices. This is why a special permission had been granted for this particular ETICS, which differed significantly from the approval in essential details.

On the basis of this analysis the project group concluded that:

$>$ with regard to the fire scenario "flames of a fully developed room fire" the small-scale fire tests (as per DIN 4102-1, DIN EN 13501-1) and, where necessary, the large-scale fire test (as per draft E DIN 4102-20), both used in approval procedures for ETICS in Germany, were sufficient for assessing the fire performance of the ETICS. The ETICS can be considered as safe, if the fire safety measures set out in the approvals are observed.

$>$ However, for certain external fire scenarios, additional fire safety measures may be required.

As a result, the project group recommended conducting research into this last point.

\section{OLDER RESULTS OF INVESTIGATIONS OF EXTERNAL FIRE SOURCES}

Fires outside a building near the facade can start from the adjacent ground or from external building elements, such as balconies or loggias. However, due to the limited dimensions of the latter, the quantity of combustible materials which can be stored there is restricted (mostly seating furniture or packaging). A higher risk is posed by burning cars or waste containers. Concerning such risks, a couple of tests with different fire sources were performed in the late 1990 and the early 2000 years at MFPA Leipzig. For the tests external fire sources were placed in front of an even test wall (no corner configuration). Table 1 gives on overview of the fire sources tests carried out at that time and their results. The flame heights measured show that the first storey is always in danger in case of such external fire. If the façade is made of flammable material there is also a risk that the fire spreads to the second storey.

This summary of results together with some explanations was also available to the project group for its consultations. It provided the basis for the following reference fire scenario to be used in the proposed research program on fire performance polystyrene-based ETICS under fire exposure from outside the building. The project group suggested using a mixed waste container with a maximum heat release of about $2.4 \mathrm{MW}$ as a reference test scenario. It is considered to also be representative of similar fire hazards, like burning small cars, motor bikes or smaller bulky waste piles.

\section{THE RESEARCH PROGRAM}

\subsection{General}

After BMK endorsed the recommendations of the project group (cf. clauses 2 and 3) in spring 2013 Deutsches Institut für Bautechnik (DIBt) was mandated to organize a research program for detailed investigations into the fire performance polystyrene-based ETICS classified as class B1 in accordance with DIN 4102-1 [5] or classes B/C in accordance with EN 13501-1 [6], under exposure to external fires starting near the base of the building. These ETICS can be used on facades of buildings of building classes 4 and 5 (buildings up to about 25 metres high) pursuant to the Model Building Code (Musterbauordnung, $M B O$ [7]). For technical and scientific steering of the programme, a small group was set up consisting of experts in façade-related fire safety issues. 
$2^{\text {nd }}$ International Seminar for Fire Safety of Facades, Lund (Sweden), 2016

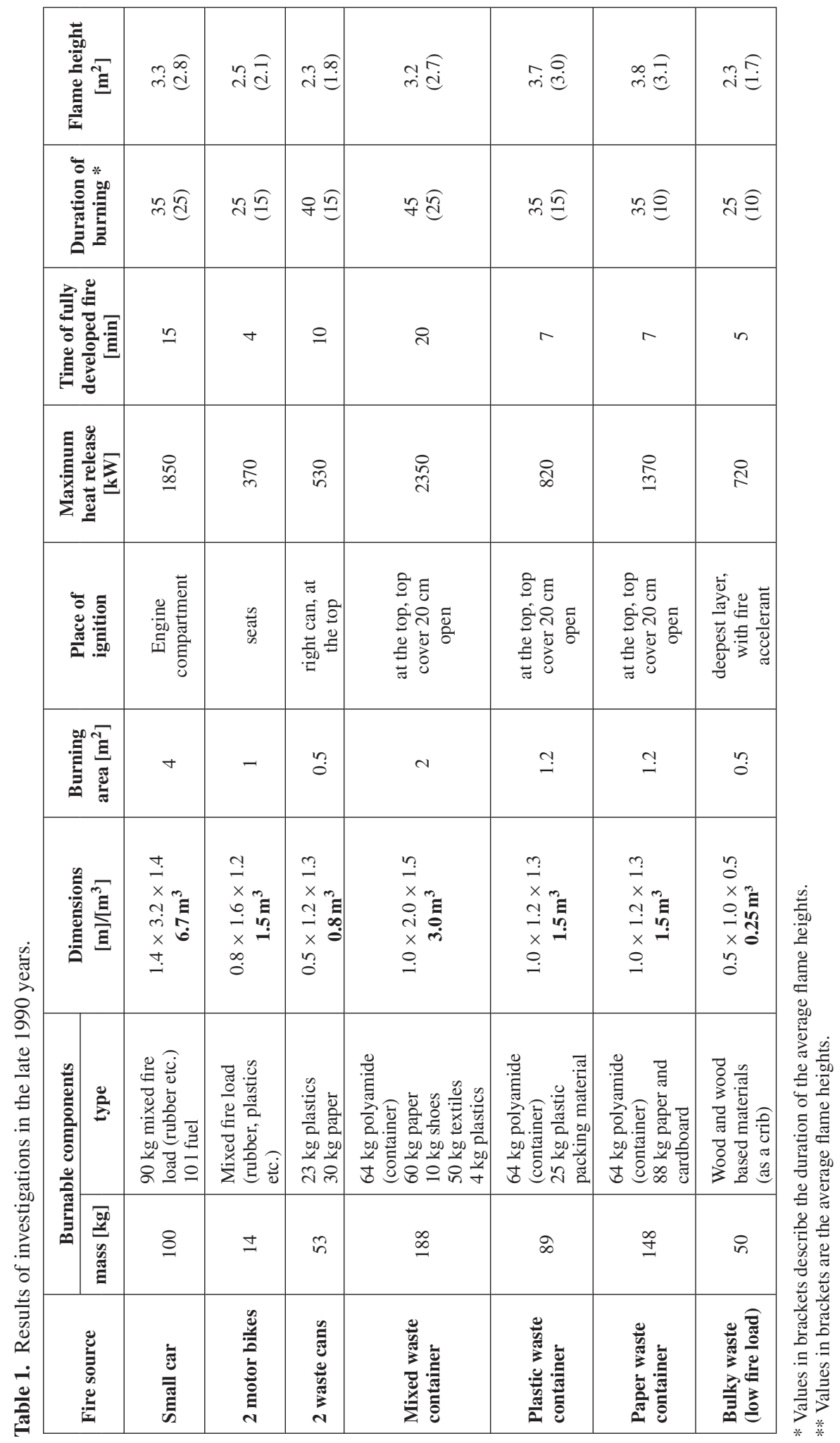



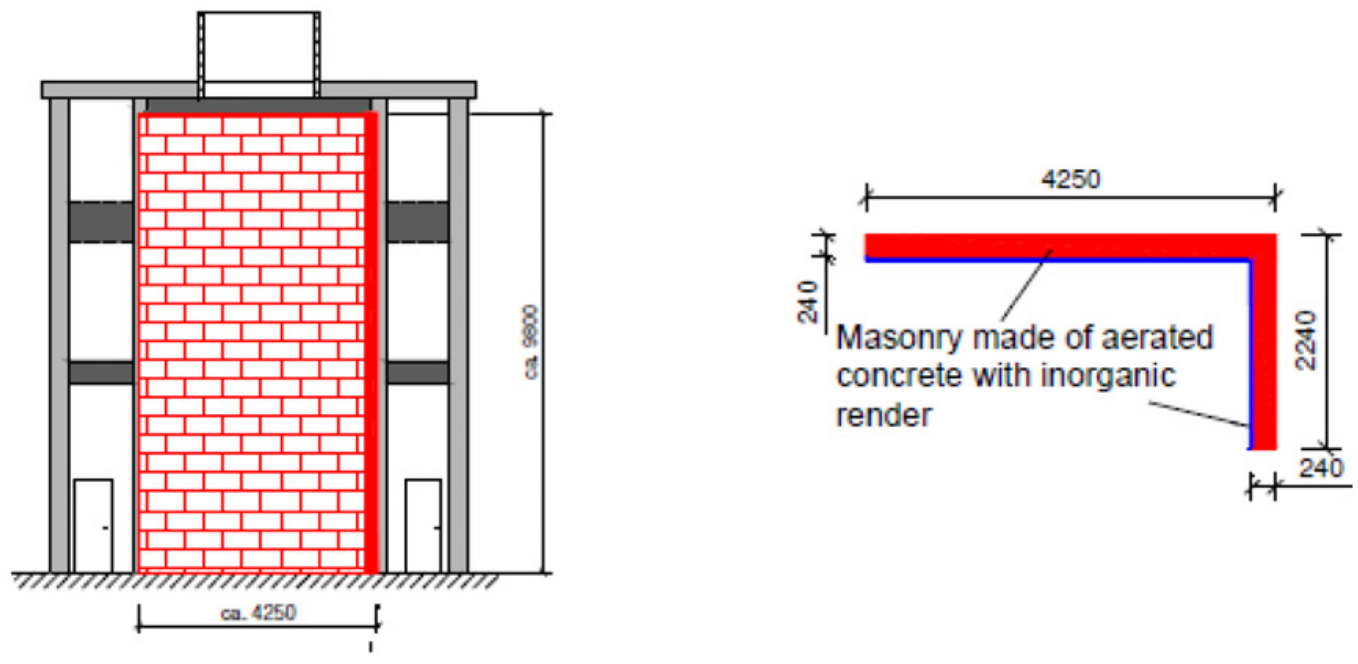

Figure 1. Front view and ground view of the test rig.

First of all, the expert group decided to use a special test rig for large-scale ETICS tests. This test rig consists of a main front and a wide wing set up at a $90^{\circ}$ angle to each other (similar to the test setup described in draft standard E DIN 4102-20 [2] or standard BS 8414-1 [8]), but with a height of about $10 \mathrm{~m}$ and without a fire chamber at the base of the main front. The test rig was made from aerated concrete stones (density $\sim 600 \mathrm{~kg} / \mathrm{m}^{3}$ ) and set up in a testing hall of MFPA Leipzig, protected from the weather. Its height results from the expected flame height of the fire source and an additional area needed for observation of the extension of the flame plume and the fire spread on the surface of the ETICS. The height of the test rig roughly equals the height of a 3-storey building section. Figure 1 shows the layout and front view of the test rig.

The investigations comprise three stages, which are described below.

\subsection{Testswith various waste containers and a $200 \mathrm{~kg}$ wood crib}

The first stage of the research programme consisted of tests performed on various waste containers. This was considered necessary, because - unlike in the late 1990s - a strict waste separation system has been in place in Germany for some years and mixed waste containers have become very rare. The tests were aimed at confirming that containers filled with homogenous waste do not lead to higher heat release rates than 2.4 MW as assumed in the recommendation of the BMK project group (cf. Sect. 3 above).

It was clear from the start that for the large-scale ETICS tests an appropriate, well-reproducible fire source other than a waste container had to be found. The steering group intensively discussed the use of a wood crib with about $200 \mathrm{~kg}$ wood as well as a pool fire of isopropanol. The former behaves similarly to a burning waste container, in particular in the starting phase of the fire, because of the gradual fire development. Stable flame plume and high flames for the most part of the test duration are further advantages of the wood crib. By contrast, a pool fire leads to a sudden fire exposure of the facade (untypical of waste containers). But good reproducibility is an advantage of this fire source.

After weighing the advantages and disadvantages of both fire sources, the steering group decided to use a wood crib of $200 \mathrm{~kg}$ spruce wood as a primary fire source for the large-scale ETICS tests. For this fire source, the expected averaged heat release was about 2.0-2.3 MW with peaks between 2.5 and 3.0 MW based on available experience, calculations and old internal test results from MFPA Leipzig. The area of the area of the wood crib should be $1.1 \mathrm{~m} \times 1.1 \mathrm{~m}$. The cross-section of the wood sticks 

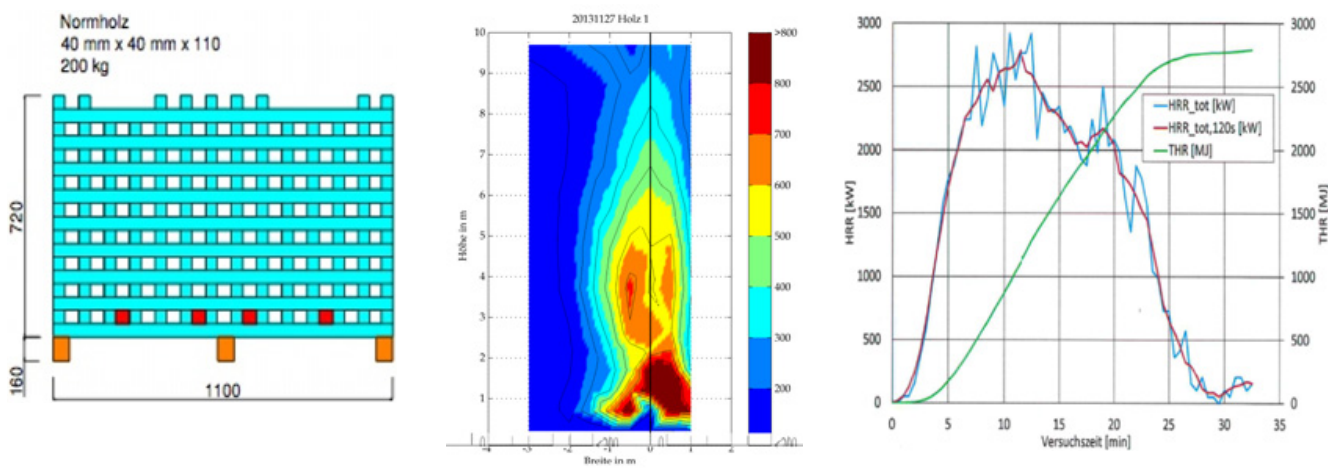

Figure 2. Drawing, time-independent maximum isotherms and heat release rate of the wood crib (from left to right).

was $40 \mathrm{~mm} \times 40 \mathrm{~mm}$ and the sticks were stacked lengthways and widthways in alternating layers with a wood : air ratio of $1: 1$. The total height of the wood crib was about $70 \mathrm{~cm}$. Figure 2 shows the wood crib.

Six tests had been performed in total within the framework of these investigations:

- 1 paper waste container (made up of about $60 \mathrm{~kg}$ polypropylene, filled with about $71 \mathrm{~kg}$ paper / cardboard),

- 1 plastic waste container (made up of about $60 \mathrm{~kg}$ polypropylene, filled with about $52 \mathrm{~kg}$ plastic waste),

- combination of 1 paper waste container and 1 plastic waste container (as described before),

- 3 test with $200 \mathrm{~kg}$ wood crib (1 x trial, $1 \mathrm{x}$ repetition, and $1 \mathrm{x}$ demonstration to $B M K$ project group).

The following parameters were determined during the tests:

- temperatures in front of the test rig using a grid of thermocouples,

- flame heights and flame plumes with video camera,

- mass loss by using a scale.

Temperatures were used for creating pictures of isotherms. Mass loss data together with mass-weighted averaged gross calorific values served as a basis for calculating heat release rates during the tests. (cf. Fig. 2)

Table 2 gives an overview on the main results of these tests. In December 2013 they had been presented to project group of BMK (including members of fire brigades). The project group confirmed that the $200-\mathrm{kg}$-wood crib covers more than $90 \%$ of external fires affecting facades such as storages within relocations, waste in normal amounts including bulky waste or typical automobiles.

\subsection{Selection of the ETICS and required laboratory tests}

With support of DIBt as the German approval body in the construction sector, the steering group chose an approved ETICS considered to be representative of a wide range of polystyrene-based ETICS available on the German market. On the basis of existing test experience with such ETICS, the following requirements were set out for the test ETICS:

- use of an polyurethane-based adhesive foam for fixing to the substrate,

- white polystyrene with a thickness of $300 \mathrm{~mm}$ and an apparent density of about $25 \mathrm{~kg} / \mathrm{m}^{3}$,

- base coat with organic binders, $2 \mathrm{~mm}$ thick, about $10 \%$ organic compounds in dried condition),

- glass fibre mesh as reinforcement with an weight per unit area of about $150 \mathrm{~g} / \mathrm{m}^{2}$, 


\section{MATEC Web of Conferences}

Table 2. Overview on results of test with waste containers and the 200-kg-wood crib.

\begin{tabular}{|c|c|c|c|c|c|c|}
\hline $\begin{array}{c}\text { Fire } \\
\text { source }\end{array}$ & Fire load & \begin{tabular}{|c|} 
Mass- \\
weighted \\
cross \\
calorific \\
value $[\mathrm{MJ} / \mathrm{kg}]$
\end{tabular} & \begin{tabular}{|} 
Maximum \\
flame \\
height \\
[m]
\end{tabular} & $\begin{array}{c}\text { Maximum } \\
\text { heat } \\
\text { release } \\
{[\mathrm{MW}]}\end{array}$ & $\begin{array}{c}\text { Total heat } \\
\text { release } \\
\text { after } \\
25 \text { minute } \\
{[\mathrm{MJ}] *}\end{array}$ & Short description of the tests \\
\hline $\begin{array}{c}\text { Paper } \\
\text { waste } \\
\text { container }\end{array}$ & $\begin{array}{c}\sim 60 \mathrm{~kg} \text { polypro- } \\
\text { pylene (container) } \\
\sim 71 \mathrm{~kg} \text { paper and } \\
\text { cardboard }\end{array}$ & 30.4 & $\begin{array}{c}2.5-3.0 \\
\text { (short peaks } \\
\text { up to } 4)\end{array}$ & $\sim 2.0$ & $\sim 800$ & $\begin{array}{l}\text { - fire starts very slowly due to } \\
\text { compact filling of the waste } \\
\text { - more intensive fire only after } \\
12 \text { minutes } \\
\text { - only } 60 \mathrm{~kg} \text { of paper and plas- } \\
\text { tic burnt after } 60 \text { minutes }\end{array}$ \\
\hline $\begin{array}{c}1 \text { Plastic } \\
\text { waste } \\
\text { container }\end{array}$ & $\begin{array}{c}\sim 60 \mathrm{~kg} \text { polypro- } \\
\text { pylene (container) } \\
\sim 52 \mathrm{~kg} \text { mixes } \\
\text { plastic waste }\end{array}$ & 41.9 & $\begin{array}{c}2.5-3.0 \\
\text { (short peaks } \\
\text { up to } 4)\end{array}$ & $\sim 5.0$ & $\sim 2100$ & $\begin{array}{l}\text { - fire starts very slowly due to } \\
\text { compact filling of the waste } \\
\text { - intensive fire starts more than } \\
10 \text { minutes after ignition } \\
\text { - development of an intensive } \\
\text { pool fire after } 21 \text { minutes } \\
\text { - only } 55 \mathrm{~kg} \text { in total burnt } \\
\text { after } 26 \text { minutes }\end{array}$ \\
\hline \begin{tabular}{|c|} 
Paper \\
waste \\
container \\
+ \\
1 Plastic \\
waste \\
container \\
\end{tabular} & $\begin{array}{c}2 \times \sim 60 \mathrm{~kg} \\
\text { polypropylene } \\
(\text { containers }) \\
\sim 55 \mathrm{~kg} \text { plastic } \\
\text { waste }+ \\
53 \mathrm{~kg} \text { paper and } \\
\text { cardboard }\end{array}$ & 36.5 & $4.0-4.5$ & $\sim 6.7$ & $\sim 4000$ & $\begin{array}{l}\text { - fully developed fire already } \\
\text { after } 7 \text { minutes } \\
\text { - development of an intensive } \\
\text { expanded pool fire after } \\
10 \text { minutes }\end{array}$ \\
\hline $\begin{array}{c}200 \mathrm{~kg} \\
\text { wood crib } \\
(3 \text { test })\end{array}$ & $\begin{array}{c}200 \mathrm{~kg} \text { spruce } \\
\text { wood }\end{array}$ & 15.8 & $\begin{array}{c}4-5 \\
\text { (short peaks } \\
\text { up to } 7 \text { ) }\end{array}$ & $\mathrm{s} \sim 2.8 / 3.2 /$ & $\begin{array}{c}\sim 2750 \\
\text { (in all } 3 \text { tests) }\end{array}$ & $\begin{array}{l}\text { - stable flame plume after } \\
\text { about } 5 \text { minutes } \\
\text { - total collapse of the } \\
\text { crib after } 25 \text { minutes } \\
\text { - about } 180 \mathrm{~kg} \text { wood burnt } \\
\text { after } 30 \text { minutes }\end{array}$ \\
\hline
\end{tabular}

* This period of time reflects the lapse of time between the start of the fire and the latest start of fire-fighting measures (usual in Germany).

- finishing coat with organic binders, $2 \mathrm{~mm}$ thick, about $10 \%$ organic compounds in dried condition,

- $60 \mathrm{~cm}$ high splash water zone made up with polystyrene, $240 \mathrm{~mm}$ thick, organic rendering and a profile made of PVC at the lower edge of the ETICS.

An independent local specialised firm was contracted to acquire the components and install the ETICS on the test rig for the large-scale tests to ensure that ETICS manufacturers had no influence on the test results. For the same reason, test specimens of the ETICS, the polystyrene insulation material, the render coats and the PU foam were prepared for small-scale reaction to fire tests as per DIN 4102-1 and further laboratory tests in order to check whether the provisions of the ETICS approval were met. The following tests had been done:

- determination of apparent density and reaction to fire class as per DIN 4102-1 of the polystyrene,

- determination of ash content of the base and finishing coats as per ETAG 004, annex C [9],

- determination of reaction to fire class as per DIN 4102-1 of the ETICS itself and

- determination of reaction to fire class as per DIN 4102-1 of the PU adhesive foam.

All of these laboratory tests were performed twice by two different testing laboratories (MPA Braunschweig and BAM Berlin), independently of each other. The test results confirmed that the approval requirements and the specifications of the steering group for the ETICS itself as well as for its components were met - except for the reaction to fire class of the PU adhesive foam. The latter did not meet the requirements for reaction to fire class B2 as per DIN 4102-1 for unknown reasons. However, 

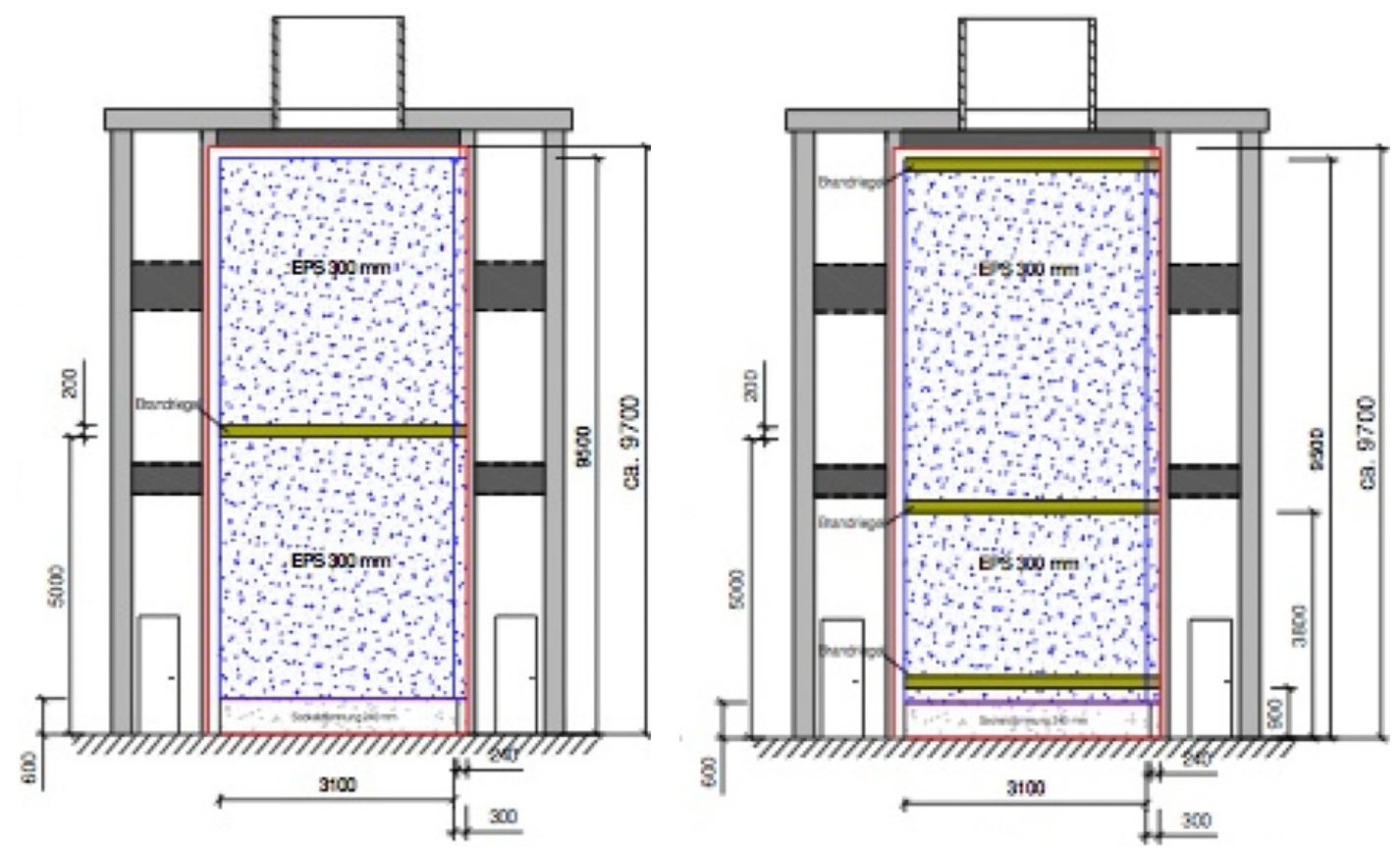

Figure 3. Position of the fire barriers (in Green) in test 1 (left) as well as in tests 2 and 3 (right).

with regard to the large-scale tests this means that an especially critical ETICS design (including the fixing) has been tested.

\subsection{The large-scale tests}

Within the framework of the investigation, three large-scale tests had been performed in total in 2014 The minimum test duration had been agreed to be 25 minutes, because - according to the fire brigades - it usually takes 8-10 minutes until an external fire is discovered and another 10-15 minutes until the fire-fighters arrive. The wood crib (as described in Sect. 4.2) was placed directly in the corner of the test rig with a distance of about $10 \mathrm{~cm}$ from the surface of the ETICS. It was ignited by a spark pistol and fuelled by 4 small trays each with $200 \mathrm{ml}$ isopropanol placed in the second layer of the wood crib. Assembly of the The ETICS complied with the basic requirements given in Sect. 4.3 for all three tests.

Test 1 was aimed at verifying the fire performance of polystyrene-based ETICS as observed by fire brigades under standardised conditions and determining its causes. The ETICS design used for test 1 included only one fire barrier positioned $5.0 \mathrm{~m}$ above the floor of the testing hall. This roughly corresponds to one fire barrier every second storey, as required by approvals in the past. An adhesive (mortar) with organic binders was used for fixing of the fire barrier to the substrate without additional mechanical fixing (anchors). Fire barriers consisted of mineral wool lamella stripes, $200 \mathrm{~mm}$ thick, with reaction to fire class A1 as per EN 13501-1, apparent density of about $90 \mathrm{~kg} / \mathrm{m}^{3}$ and a melting point of $>1000{ }^{\circ} \mathrm{C}$ (tested as per DIN 4102-17 [10]). Figure 3 shows the test setup including the position of the fire barriers in test 1 as well as in tests 2 and 3 .

Observations during the test and results of test 1 :

- ignition and development of an independent fire on the render surface about 7 minutes after the beginning of the test - flame travels upwards leaping over the fire barrier, 


\section{MATEC Web of Conferences}

- formation of a secondary fire at base of the wood crib, caused by molten polystyrene in the $9^{\text {th }}$ test minute,

- strong deformation of the render, in particular on the short wing of the test rig before the end of the $10^{\text {th }}$ test minute,

- extension of the flames of the primary fire source through energetic contribution of the ETICS up to the top edge of the test rig in the $11^{\text {th }}$ test minute (flame height $\approx 10,0 \mathrm{~m}$ ),

- cracking of the render on the short wing near the inner corner of the L-shaped test rig in the $12^{\text {th }} /$ $13^{\text {th }}$ test minute - subsequently, increasing lateral fire spread and intensive smoke development,

- large parts of the rendering come loose in the $15^{\text {th }}$ test minute - parts of the fire barrier probably come off at this time at the latest,

- fully developed fire after 15 minutes combined with intensive smoke development - temperatures of $\geq 1200^{\circ} \mathrm{C}$ measured in the chimney above the test rig,

- secondary pool fire on the floor of the testing hall is extinguished after the $19^{\text {th }}$ test minute; the wood crib is extinguished after 28 minutes $=$ end of the test.

- After the end of the test, the ETICS including the PU foam layer between the insulation layer and the substrate is found to have been completely combusted.

Results of test 1 were considered as negative and unacceptable with regard to the safety objectives of the building codes. This opinion was shared by both the members of the $B M K$ project group as well as the members of the steering group. The findings confirmed observations made by the fire brigades during real fires.

Afterwards for the two further arrangements for improving the fire performance of the ETICS were considered. For that the number of fire barriers was increased and their fixing modified. Additionally, the reinforcement of the base coat was strengthened with a special mesh corner bracket at the inner corner of the ETICS test rig. The first fire barrier was positioned almost immediately above the splash water zone; the second fire barrier in a distance of about $3.0 \mathrm{~m}$ above the first one and the third fire barrier directly at the top of the test rig (cf. Fig. 3). Furthermore, an inorganic adhesive (binders: lime/cement) and approved anchors (consisting of sleeves and plates made of plastics and a steel expansion element) were used for their fixing.

Observations during the test and results of the second test:

- intensive exposure of the ETICS to flames shooting up from the wood crib after 4/5 minutes,

- combustion of the insulation material of the splash water zone as well as that of the ETICS, but below the first fire barrier only,

- rendering above the first fire barrier up to the top edge of the test assembly does not crack during the entire test duration,

- only the flames of the primary fire source (wood crib) extend up to a height of about 6-7 m due to combustion of the organic base and finishing coat compounds as well as pyrolysis gases from the polystyrene diffusing trough the render layer,

- development of a secondary fire at the base only after more than 20 minutes,

- fire barriers remain attached to the substrate,

- the wood crib is only extinguished after 35 test minutes - at that time, the fire intensity is clearly decreasing.

Comparison of these results with the results of the pre-tests on waste containers and the wood crib shows only slight differences in flame heights and fire spread on the surface of the ETICS, meaning that the contribution of the ETICS to fire spread was very limited. With regard to the safety objectives set out in the building codes - limiting the number of storeys affected by fire at the very most by the time the fire brigades arrive to 2 storeys - results of test 2 were considered positive.

The third test confirmed the results of the second test. The observations during the test and the damages at the end of the test were similar. Only the flames of the wood crib shot up higher. These differences were essentially caused by different wind and weather conditions at the time of testing 

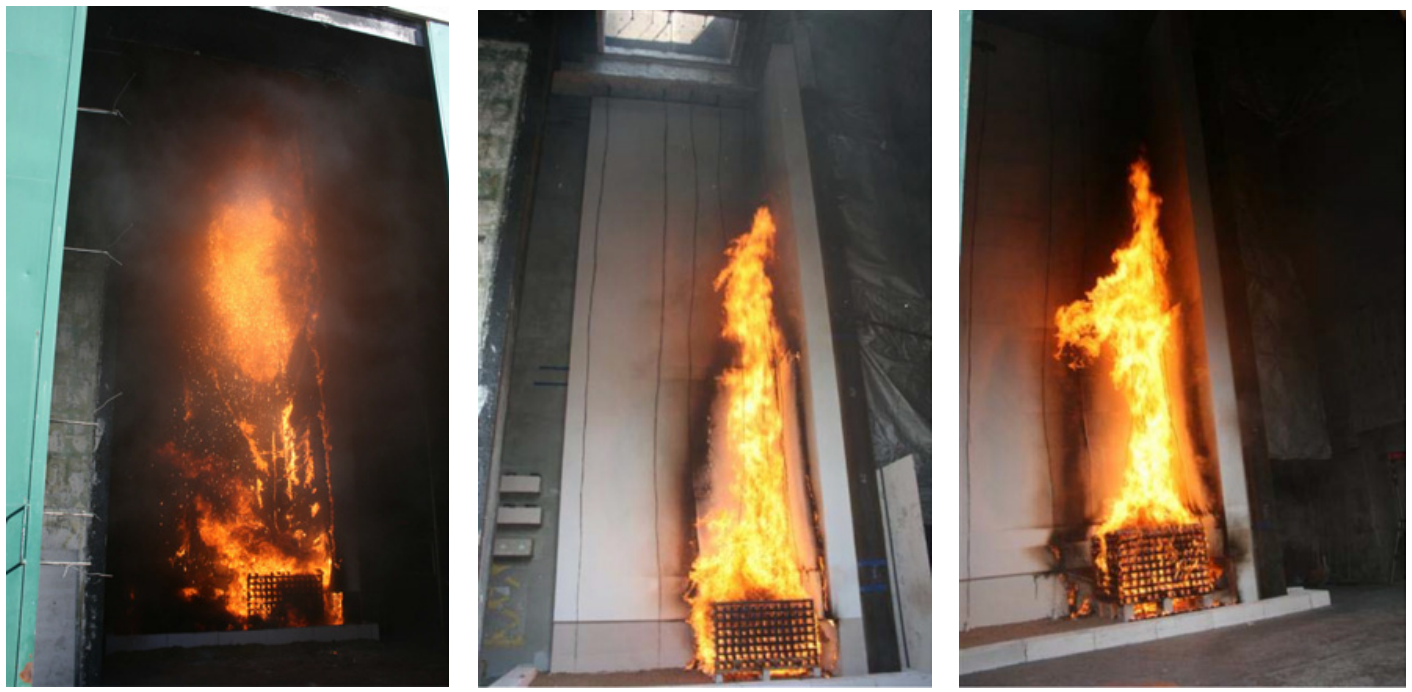

Figure 4. Test 1 at the 15 th minute (left); test 2 and 3 at the 18th minute (middle and right).
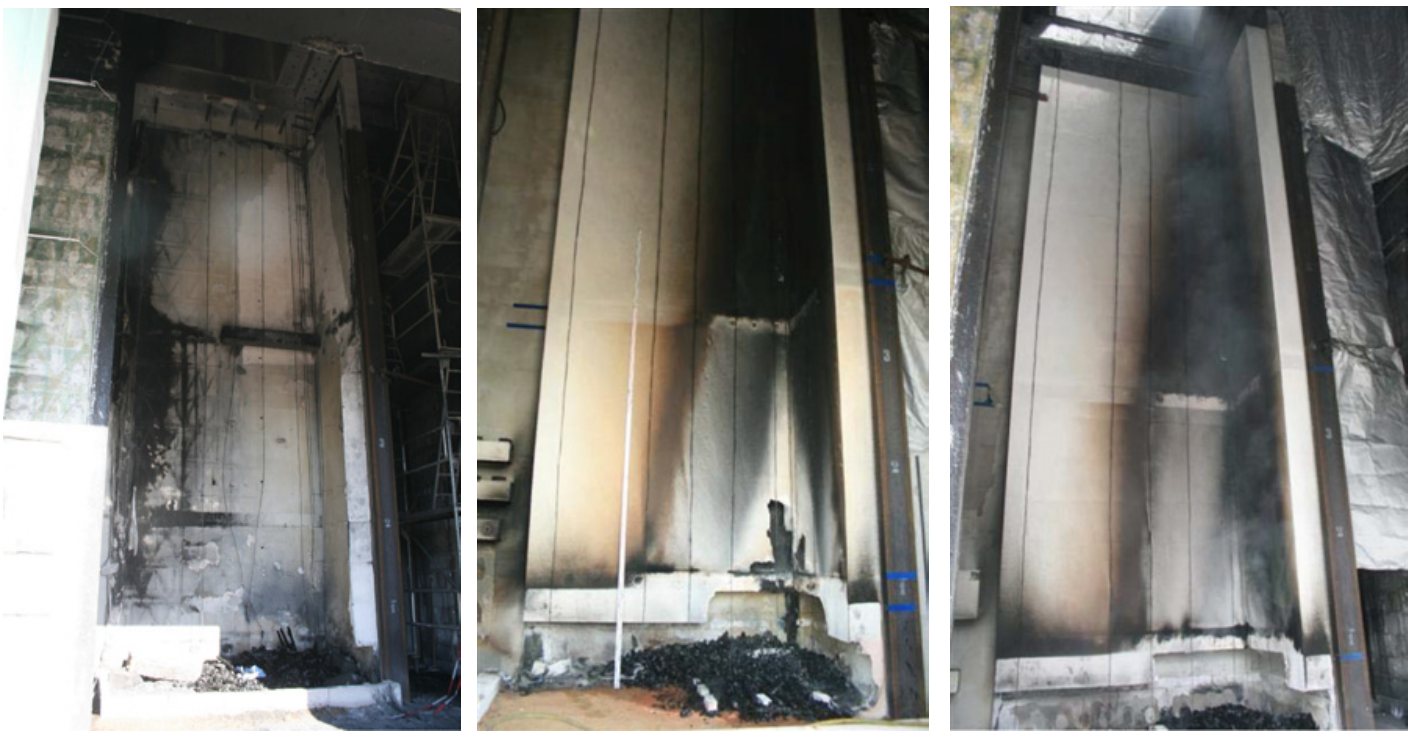

Figure 5. Damage of the ETICS assemblies after end of tests 1 to 3 (from left to right).

between test 2 and 3. Figures 4 and 5 give an impression of the three large-scale tests performed within the framework of the research programme.

After the end of the research programme, the steering group and the $B M K$ project group jointly discussed whether the scenario "external fire exposure" should also be applied to other external wall cladding systems than polystyrene-based ETICS. The members unanimously came to the conclusion that this was not necessary, since there was no evidence pointing to the involvement of such systems in serious fires. Furthermore, the insulation materials used for these systems (mineral wool, polyurethane 
foam, phenolic resin foam) do not show the same thermoplastic reaction under fire exposure as polystyrene (including melting and formation of pools near the primary fire source).

\section{LESSONS DRAWN FROM THE TEST RESULTS}

In autumn 2014, the results of the research programme were presented to the Conference of Construction Ministers $(B M K)$. At the meeting, the ministers endorsed the proposal to amend all national approvals granted by DIBt for polystyrene-based ETICS rated as class B1 in accordance with DIN 4102-1 or classes B/C in accordance with EN 13501-1 and impose additional fire safety requirements relating to fire exposure from outside the building.

The expert group "Reaction to fire of construction materials" (advising DIBt in fire safety matters related to approvals) agreed unanimously that the "area at risk", i.e. the part of the façade that needed additional protection against external fire exposure comprised the area of the first three storeys of a building, because a critical impact is not to expect above this area caused by such external fire near building's base. Hence, the fire safety measures proved in the large-scale tests should be introduced in the approvals of those ETICS covered by the tests in the following form:

- position of the first fire barrier directly above the splash water zone, no higher than $90 \mathrm{~cm}$ above the ground,

- position of the second fire barrier at the height of the ceiling above the first storey, but with no greater distance from the first fire barrier than $3.0 \mathrm{~m}$,

- position of the third fire barrier at the height of the ceiling of the third storey, but with no greater distance from the second fire barrier than $8.0 \mathrm{~m}$,

- integration of a special mesh corner bracket in the reinforced base coat in inner corners of buildings,

- use of further fire barriers in the area of transitions between the external wall and horizontal building elements, e.g. balconies, if these transitions are situated in the "area at risk".

The fire barrier design (type, dimensions, fixing) has to be identical to that tested in large-scale tests 2 and 3. These fire barriers also serve as a protection against possible fire exposure to flames of a fully developed room fire.

However, the consultations of the expert group also showed that the results of the research programme mainly cover the tested ETICS design, but not the entire field of polystyrene-based ETICS. The test results are only valid for ETICS corresponding to the following specifications:

- application on inorganic substrates, such as masonry or concrete,

- fixed with adhesives (mortar or PU foam) only or in combination with anchors or profiles,

- use of polystyrene of class B1 in accordance with DIN 4102-1 or classes B / C in accordance with EN 13501-1, with a thickness of up to $300 \mathrm{~mm}$ and a maximum apparent density of $25 \mathrm{~kg} / \mathrm{m}^{3}$,

- use of glass fibre meshes with a weight per unit area of at least $150 \mathrm{~g} / \mathrm{m}^{2}$ as a reinforcement and

- use of base coats and finishing coats, each with no more than $10 \%$ of organic compounds in dried condition, with a total thickness of the rendering of at least $4 \mathrm{~mm}$.

These specifications cover about two-third of polystyrene-based ETICS approved in Germany.

All members of the expert group agreed that the fire safety measures described above are not sufficient for polystyrene-based ETICS:

- in case of application on substrates made of wood or wood-based panels,

- with insulation layers of a thickness of more than $300 \mathrm{~mm}$,

- with ceramic or natural stone claddings (due to the risk of spalling under fire exposure and subsequent damage to the reinforced base coat) or

- without a reinforced base coat.

After intensive discussions and based on technical considerations, it has been decided to require noncombustible external wall cladding systems (usually an ETICS based on mineral wool) in the area of 
the first two storeys and installation of an additional fire barrier at the height of the ceiling of the third storey in these cases - until further test results are available.

In May 2015, DIBt published an information leaflet [11] on its homepage containing a detailed description and schematic drawings of the additional fire safety measures required for the various types of polystyrene-based ETICS. On the basis of this information, more than 250 approvals were amended in the summer and autumn of 2015. As of $1^{\text {st }}$ January 2016, these amendments have entered into force and have to be considered when installing a polystyrene-based ETICS on site.

\section{CONCLUSION}

A couple of particularly serious fires and extensive media coverage of these events triggered an investigation into fire incidents involving external thermal insulation composite systems (ETICS) based on polystyrene which occurred over the last few years. The investigation showed that the fires and their spread over the facade of the building were often caused by fire exposure from outside the building, e.g. burning waste containers. For this reason, a research programme was carried out in order to determine the intensity of such waste container fires, to verify the reaction of polystyrene-based ETICS observed in real fires under standardised conditions and to test appropriate safety measures to improve the fire performance of these ETICS. The results of the research programme showed that additional fire safety measures against fire exposure from the outside near the base of the building were required - mostly taking the form of fire barriers running around the building and made of non-combustible mineral wool lamella stripes positioned above the splash water zone and at the heights of the ceilings of the first and third storey. These measures were specified in detail and introduced into all national approvals of DIBt for polystyrene-based ETICS granted by DIBt. Since the beginning of 2016, their application has been mandatory in Germany.

At present, consideration of the scenario "fire from the outside near the base of a building" is only necessary for polystyrene-based ETICS. For other external wall cladding systems, there has been no evidence so far pointing to an unacceptable performance of these systems in case of such fires.

\section{References}

[1] ISO 13785-2:2002 Reaction-to-fire test for facades - part 2: Large-scale test.

[2] Draft E DIN 4102-20:2016-03 "Fire performance of construction materials and building elements; part 20: Special determination of the fire performance of external wall cladding systems".

[3] Kottoff, Riemesch-Speer, "Mechanism of fire spread on facades and the new Technical Report of EOTA Large-scale fire performance testing of external wall cladding systems", Proceedings of the $1^{\text {st }}$ seminar "Fire safety of facades", Paris 2013.

[4] Internal progress report of the project group "Fire performance of ETICS with polystyrene insulation" to the meeting of the conference of Länder ministers responsible for building ('Bauminsterkonferenz' - BMK), held on 22 March 2013 - unpublished.

[5] DIN 4102-1:1998-05 "Fire behaviour of building materials and elements; part 1: requirements and testing of the reaction to fire of building materials".

[6] EN 13501-1:2010 "Classification of building products; part 1: classification of building products with the results of tests to their reaction to fire".

[7] Model Building Code (Musterbauordnung, MBO), version 2012, issued by the Conference of Länder ministers responsible for building; www . is-argebau. de.

[8] Standard BS 8414-1 "Fire performance of external wall cladding systems", part 1 dated $13^{\text {th }}$ December of 2002. 


\section{MATEC Web of Conferences}

[9] ETAG 004 - "Guideline for European Technical Approvals of External Thermal Insulation Composite Systems (ETICS) with Renderings", published by the European Organization for Technical Approvals (EOTA): edition February 2013.

[10] DIN 4102-17:1990-12 "Fire behaviour of building materials and elements; part 17: Melting point of mineral wool insulation materials; requirements and testing of the reaction to fire of building materials".

[11] Information on ETICS with EPS insulation published by DIBt, version: 27 May 2015, www.dibt.de $\rightarrow$ Departments $\rightarrow$ Unit II1. 